ACTA VET. BRNO 2001, 70: 375-379

\title{
ULTRASTRUCTURE OF THE OLFACTORY EPITHELIUM OF KITTENS
}

\author{
I. KOCIÁNOVÁ, F. TICHÝ, A. GOROŠOVÁ \\ Department of Anatomy, Histology and Embryology, Faculty of Veterinary Medicine, \\ University of Veterinary and Pharmaceutical Sciences, Brno, Czech Republic \\ Received March 22, 2001 \\ Accepted October 31, 2001

\section{Abstract} \\ Kociánová I., F. Tichý, A. Gorošová: Ultrastructure of the Olfactory Epithelium of \\ Kittens. Acta Vet. Brno 2001, 70: 375-379. \\ The structure of the olfactory epithelium of a 35-to-40-day-old kitten was studied by \\ transmission electron microscopy. The samples were collected from the ethmoidal labyrinth. At \\ this stage of development, the regio olfactoria was lined by a typical pseudostratified olfactory \\ epithelium built of olfactory cells, sustentacular cells, and basal cells. The height of the epithelium \\ varied between 16 and $18 \mu \mathrm{m}$. A characteristic feature of the free surface of the epithelium was \\ a considerable degree of differentiation. Protruding above the surface were endings of dendritic \\ projections of sensory cells with a diameter of 0.8 -to- $1.0 \mu \mathrm{m}$ carrying numerous atypical cilia and \\ 1.0-to-1.5 $\mu \mathrm{m}$ long microvilli of sustentacular cells. Supranuclear segments of the supportive and \\ olfactory cells contained a large amount of rough and smooth endoplasmic reticulum and numerous \\ elongated mitochondria. Long dendritic projections of the olfactory cells were closely surrounded \\ by apical cytoplasm of the sustentacular cells. Contacts among the cells were provided by close \\ intercellular links. The data on the structure of the olfactory epithelium of 35-to-40-day-old kittens \\ indicate that the epithelium at this age is fully functional. \\ Sense organs, transmission electron microscopy, olfactory epithelium, ontogenesis
}

The structure of the olfactory epithelium of various animal species was studied by several authors (Menco 1977; Menco et al. 1976, 1978; Hinds et al. 1984; Constanzo and Morrison 1989; Naguro and Iwashita 1992). Generally, they describe it as a pseudostratified epithelium containing sensory, sustentacular, basal, and microvillar cells with their specific positions and functions. Organelle outfit of the epithelial cells and some of their structural characteristics are subject to changes during the maturation of the mucosa (Graziadei 1974; Menco 1977; Getchel 1986). Another cell type, characterised by the presence of microvilli, oval bodies immediately below the free surface, and dendrite-like apical projections, was described by Agasandyan (1990), Morrison and Constanzo (1990, 1992), Morrison and Moran (1994), and Ota (1998).

This study deals with the ultrastructure of the olfactory epithelium of a kitten aged 5 to 6 weeks. Attention was paid to the structure of supranuclear and perinuclear parts and organelles of the epithelial cells and to the formation of dendritic projections on the one hand and to the development of the structure of the free surface of sustentacular and sensory cells on the other hand.

\section{Materials and Methods}

The material for our investigation was obtained from the collection of the Institute of Anatomy, Histology, and Embryology of the University of Veterinary and Pharmaceutical Sciences, Brno. The tissues under study originated from three female kittens aged 35 to 40 days. The age was determined by measurement of CRL (crown-rumplength) using the method described by Evans and Sack (1973). The skull was split by a sagital cut and nasal septum was removed to expose the ethmoidal labyrinth. Samples of mucosa for electron optical examination were collected from the area of $3^{\text {rd }}$ endoturbinale and immediately fixed with $300 \mathrm{mmol} / \mathrm{l}$ glutaraldehyde in 100 $\mathrm{mmol} / \mathrm{l}$ phosphate buffer for $4 \mathrm{~h}$. The fixed material was processed by the method described by Tichý (1994). The 
tissue was washed in four changes of phosphate buffer $(100 \mathrm{mmol} / \mathrm{l})$ and postfixed in $40 \mathrm{mmol} / \mathrm{l} \mathrm{OsO}_{4}$ in 100 $\mathrm{mmol} / \mathrm{l}$ phosphate buffer for $1 \mathrm{~h}$. After dehydration in a graded acetone series $(0.25 ; 0.50 ; 0.75 ; 1.00 \mathrm{mmol} / \mathrm{l})$, the samples were embedded in Durcupan ACM and polymerised at $60{ }^{\circ} \mathrm{C}$ for 3 days. Fixation, dehydration, and embedding were carried out at room temperature; $\mathrm{pH}$ of the buffer solutions was maintained at 7.4 to 7.42. Ultrathin sections were viewed and photographed in the electron microscope Tesla BS 500.

\section{Results}

Olfactory cells

Olfactory cell bodies with nuclei occupying the middle epithelial zone sent slim, 7- to $8 \mu$ long, or even longer dendritic projections towards the surface. The projections were closely surrounded by long, clubbed supranuclear parts of sustentacular cells. Close links of the zonulae occludentes type were formed between the two cell types in the proximity of the epithelial surface and desmosomal links were also observed at deeper level in this region.

Terminal segments of the dendritic projections protruded above the surface forming spherical or oval endings with a diameter of 0.8 to $1.0 \mu \mathrm{m}$ (Plate I, Fig. 1). The cytoplasm of the endings contained sporadic vesicles of smooth endoplasmic reticulum, solitary mitochondria, and basal bodies of olfactory cilia. Centriolar replication figures were also seen in some of the endings. The olfactory cilia originated mostly from lateral surfaces of the dendritic endings and most of them ran in parallel with the free epithelial surface. The thickness of proximal segments of the cilia was 110 to $140 \mathrm{~nm}$. At a distance of approximately 0.8 to $1.0 \mathrm{~nm}$ from their origin, the proximal segments became conic and passed into distal segments with a diameter of 30 to $50 \mathrm{~nm}$. The proximal segments showed the typical arrangement of axonema (nine peripheral and one central microtubular doublets), while only one central doublet persisted in peripheral parts of the distal segments. The olfactory cilia together with microvilli of the sustentacular cells formed a dense network covering the epithelial surface including the terminal endings of dendritic segments of the olfactory cells (Plate I. Fig. 2).

\section{Sustentacular cells}

The columnar sustentacular cells were tall, and slim. Their large oval vertically oriented nuclei containing granular chromatin were situated in the upper third of the cells. Apical segments of sustentacular cells were approximately 3 to $3.4 \mu \mathrm{m}$ wide and their cytoplasm contained numerous, mostly oval, mitochondria, large cisterns of rough endoplasmic reticulum, and numerous small vesicles of smooth endoplasmic reticulum with circular, oval or irregular flattened cross sections. Small bodies with finely granular contents and glycogen inclusions were also seen here regularly (Plate II, Fig. 3). The approximately 0.3 to $0.4 \mu \mathrm{m}$ wide segment of cytoplasm immediately below the free surface of epithelium contained only sporadic small vesicles and was separated from the rest of cytoplasm by a layer of dense material formed by what is called terminal network formed by microfilaments and microtubuli (Fig. 2).

The free surface of the sustentacular cells formed small prominences and gave origin to numerous 30-to-40-nm-thick and up to 1.6- $\mu \mathrm{m}$-long microvilli (Fig. 2). The sustentacular cells were connected with sensory cells by numerous and close links.

Basal cells

The pyramid-shaped basal cells were situated at the basal membrane at rather large distances from each other without contacting each other. Their nuclei with a slightly lobular shape were smaller than the nuclei of the sensory cells and contained a high amount of chromatin. The cytoplasm was rich in mitochondria and cisterns of rough endoplasmic reticulum (Plate II, Fig. 4). 


\section{Discussion}

The ultrastructure of the olfactory epithelium of kittens aged 35 to 40 days was studied by transmission electron microscopy. As indicated by results of this study, the proportions, positions, and ultrastructure of the various cell types of the olfactory epithelium were similar to those described in other vertebrate species and their nuclei were arranged to form three zones.

The sustentacular cells were tall and slim and acquired clubbed shape towards the free epithelial surface. Their oval nuclei were seen in the extended segments of the cells at a distance of 7 to $9 \mu$ from their apical surface. This observation is consistent with earlier findings of Graziadei (1973) and is described as a zone of oval nuclei of the sustentacular cells. Towards the basal membrane, the sustentacular cells narrowed acquiring conic shape and contacted the membrane by a thin stalk. The bodies of the sustentacular cells closely surrounded olfactory cells including their projections. The arrangement described above corresponds to the assumed insulating and supporting function (Breitpohl et al. 1974). The bodies of olfactory cells were located at the middle epithelial level and their nuclei formed the zone of light round nuclei. Basal cells were distributed at the basal membrane and contacted it by their extended bases. Their nuclei formed the discontinuous zone of dark round nuclei. Neither grouping of basal cells, as described by Morris on and Constanzo (1990), nor the fourth cell type with microvilli, oval bodies and dendrite-like apical projections found by Agasandyan (1990) in the pig, Morrison and Constanzo (1990, 1992) in the man, Morris on and Moran (1994) in the man, and Ota (1998) in the mouse were seen in our samples of the olfactory epithelium of the 5- to 6-week-old kitten.

Like other authors (Naguro and Iw ashita 1992), we found a rich organelle contents in the perinuclear and, particularly, in the supranuclear cytoplasm of the sustentacular cells. This outfit consisted of numerous mitochondria, cisterns of rough endoplasmic reticulum, and plentiful cisterns of smooth endoplasmic reticulum. Moreover, the apical cytoplasm contained bodies with finely granulated contents identified as lysosomes, pigment granules, and lipofuscin-containing vesicles, as described in the mouse by Frisch (1967), in the rabbit by Mulvaney (1971), in cattle by Menco (1977), and in humans by Naessen (1971).

Apart from solitary vesicles of smooth endoplasmic reticulum, the 0.3-to-0.4- $\mu$ m-thick layer of the apical cytoplasm immediately below the free surface was free of organelles. This layer was separated from the rest of the apical cytoplasm by a distinctive dense strip formed by accumulation of fine fibrillar structures, microfilaments, and microtubuli which has been designated by Naguro and Iwashita (1992) as the terminal network. The function of this network apparently consists in the support of the microvilli present on the free cell surface (Tichý et al. 1995). Microvilli protruding from the free surface of the sustentacular cells formed a 1.25-to-1.5- $\mu$ m-thick layer.

Long and slim dendritic projections of the olfactory cells extended from the perikaryon towards the surface and were surrounded by supranuclear segments of the sustentacular cells. The sensory and sustentacular cells were interconnected by numerous links. Zonulae occludentes were formed near the surface and deeper also desmosomes were seen. Solitary desmosomes were seen observed along the whole length of the dendritic projections. This observation is consistent with data of other authors (Rafols and Getschell 1983; Constanzo and Morrison 1989) who also described close intercellular links in the olfactory epithelium of various vertebrate species. Some authors regard the relation between the olfactory and the sustentacular cells as an analogy to the relation between neurons and glia in the CNS (Connors et al. 1984; Morrison and Constanzo 1990).

Spherical or oval terminal dendritic endings protruded over the epithelial surface. The endings contained basal bodies of the olfactory cilia, fine tubules of smooth endoplasmic reticulum, mitochondria, and centrioles. The diameter of the olfactory cilia at the level of 
the proximal segments varied between 110 and $140 \mathrm{~nm}$ and their consisted of nine peripheral microtubular doublets and one central doublet. Moreover, smaller cross sections in which the tubular apparatus was reduced to a single microtubular doublet were observed. This structure is typical of the distal segments of the olfactory cilia (Menco 1977; Menco et al. 1978). The olfactory cilia contacted the long, here and there branched microvilli of the sustentacular cells forming a dense tangle on the free surface. Some authors consider the contacts among the microvilli and cilia important for the final modulation of perception of olfactory stimuli (Menco et al. 1978); Usukara and Yamada 1978).

\section{Ultrastruktura čichového epitelu kotěte}

V TEM byla studována struktura čichového epitelu kotěte ve stáří 35 - 40 dnů post partum. Vzorky byly odebrány $\mathrm{z}$ ethmoidálního labyrintu.V této fázi vývoje byla oblast regio olfactoria pokryta typickým víceřadým čichovým epitelem, v němž byly zastoupeny 3 typy buněk: čichové buňky, buňky podpůrné a buňky bazální. Výška epitelu se pohybovala v rozmezí 16 - $18 \mu \mathrm{m}$. Volný povrch epitelu se vyznačoval značným stupněm diferenciace. Nad úroveň povrchu prominovala jednak zakončení dendritických výběžků smyslových buněk o průměrné velikosti 0,8 - 1,0 $\mu$, s četnými atypickými ciliemi, jednak mikroklky buněk podpůrných. Mikroklky byly dlouhé 1,0 - 1,5 $\mu \mathrm{m}$. Supranukleární úseky podpůrných i smyslových buněk obsahovaly množství drsného i hladkého endoplazmatického retikula (ER) a početné protáhlé mitochondrie. Dlouhé dendritické výběžky smyslových buněk byly těsně obklopeny cytoplazmou apikálních částí buněk podpůrných a jejich vzájemný kontakt byl realizován těsnými mezibuněčnými spoji. Na základě zjištěných poznatků o struktuře čichového epitelu usuzujeme, že ve sledovaném období vývoje je tento epitel již plně funkční.

\section{References}

AGASANDYAN, Kh. V. 1990: Microvillar cells in swine olfactory epithelium. J. Evol. Biochem. Physiol. 26: 194-198

BREIPOHL, W., LANGWITZ, H. J., BORNFIELD, N. 1974: Topological relations between the dendrites of olfactory cells and sustentacular cells in different vertebrates. An ultrastructural study. J. Anat. 117: 89-94

CONNORS, B. W., BERNARDO, L. S., PRICE, D. A. 1984: Carbon dioxide sensitivity of dye coupling among glia and neurons of the neoocortex. J. Neurosci. 4: 1324-1330

CONSTANZO, R. M., MORRISON, E. E. 1989: Three-dimensional scanning electron microscopic study of the normal hamster olfactory epithelium. J. Neurocytol. 18: 381-391

EVANS, H. E., SACK, W. O. 1973: Prenatal development of domestic and laboratory mammals. Anat., Histol., Embryol. 2: 11-45

FRISCH, D. 1967: Ultrastructura of mouse olfactory mucosa. Am. J. Anat. 121: 87-119

GETCHELL, T. V. 1986: Functional properties of vertebrate olfactory receptor neurons. Physiol. Rev. 66: $772-$ 818

GRAZIADEI, P. P. C. 1973: The ultrastructure of vertebrates olfactory mucosa. In: The ultrastructure of sensory organs, I. Friedman (Ed.) Elsevier, Oxford, pp. 267-305

GRAZIADEI, P. P. C. 1974: The olfactory organ in vertebrates: A survey. In: Essays of the nervous systém (R. Bellairs and E. Gray, eds.), Oxford, Clarendon Press, pp. 191-222

HINDS, J. W., HINDS P. L., MC NELLY, N. A. 1984: An autoradiographic study of mouse olfactory epithelium: evidence for long-lived receptors. Anat. Rec. 210: 375-383

MENCO, B. P. M. 1977: A qualitative and quantitative investigation of olfactory and nasal respiratory surface of cow and sheep based on various ultrastructural and biochemical methods. Communications Agricultural University, Wageningen 77-13: 1-157

MENCO B. P. M., DODD G. H., DAVEY M., BANNISTER L. H. 1976: Presence of membrane particles in freezeetched bovine olfactory cilia. Nature (London) 263: 597-599

MENCO B. P. M., LEUNISSEN J. L. M., BANNISTER L. H., DODD G. H. 1978: Bovine olfactory and nasal respiratory epithelium surfaces. Cell Tiss. Res. 193: 503-524

MORRISON, E. E., CONSTANZO, R. M. 1990: Morphology of the human olfactory epithelium. J. Compar. Neur. 297: $1-13$

MORRISON, E. E., CONSTANZO, R. M. 1992: Morphology of olfactory epithelium in humans and other vertebrates. Microsc. Res. Tech. 23: 49-61 
MORRISON, E. E., MORAN, D. T. 1994: Anatomy and ultrastructure of the human olfactory neuroepithelium. In: Handbook of Olfaction and Gustation, R. L. Doty, ed. Philadelphia, Pensylvania. pp. 75-101

MULVANEY, B. D. 1971: Chemography of lysozome-like structures in olfactory epithelium. J. Cell Biol. 51: 568575

NAESSEN, R. 1971: An enquiry on the morphological characteristics and possible changes with age in the olfactory region of man. Acta Otolaryngol., Stockholm 71: 49-62

NAGURO. T., IWASHITA, K. 1992: Olfactory epithelium in young adult and aging rats as seen with highresolution scanning electron microscopy. Microsc. Res. Tech. 23: 62-75

OTA, Y. 1998: Study of the fifth-type cell in the olfactory epithelium. Nippon-Jibiinkoka-Gakkai-Kaiha. 101: 1234-1249

RAFOLS, J. A., AND GETCHEL, T. V. 1983: Morphological relations between the receptor neurons, sustentacular cells and Schwann cells in the olfactory mucosa of the salamander. Anat. Rec. 206: 87-101

TICHÝ, F., HORKÝ, D., MÍŠEK, I. 1995: Differentiation of the olfactory epithelium in sheep in ontogenesis using scanning electron microscopy. Acta vet. Brno 64: 71-77

USUKURA, J., YAMADA, E. 1978: Observations on the cytolemma of the olfactory receptor cell in the newt. Freeze replica analysis. Cell Tiss. Res. 188: 83-98 
Plate I

Kociánová I. et al.: Ultrastructure... pp. 375-379.

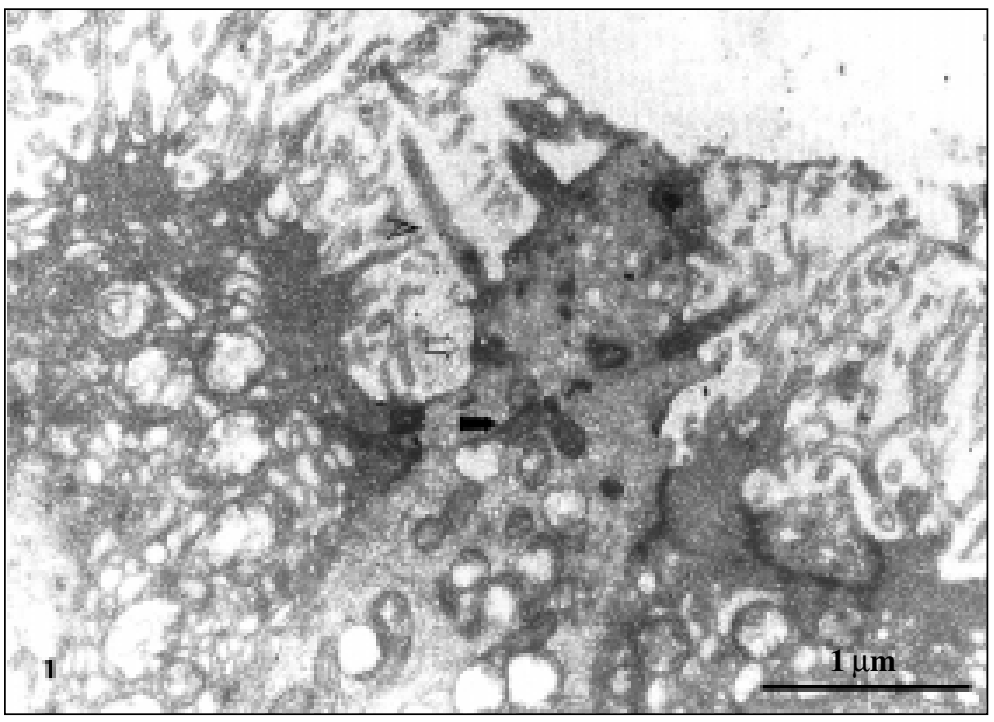

Fig.1: The ending of dendritic projection of an olfactory cell with solitary mitochondria $(\rightarrow)$ and ciliar basal bodies $(\vec{c})$ in the kitten. Proximal segments arise from lateral surface of the ending $(>)$.

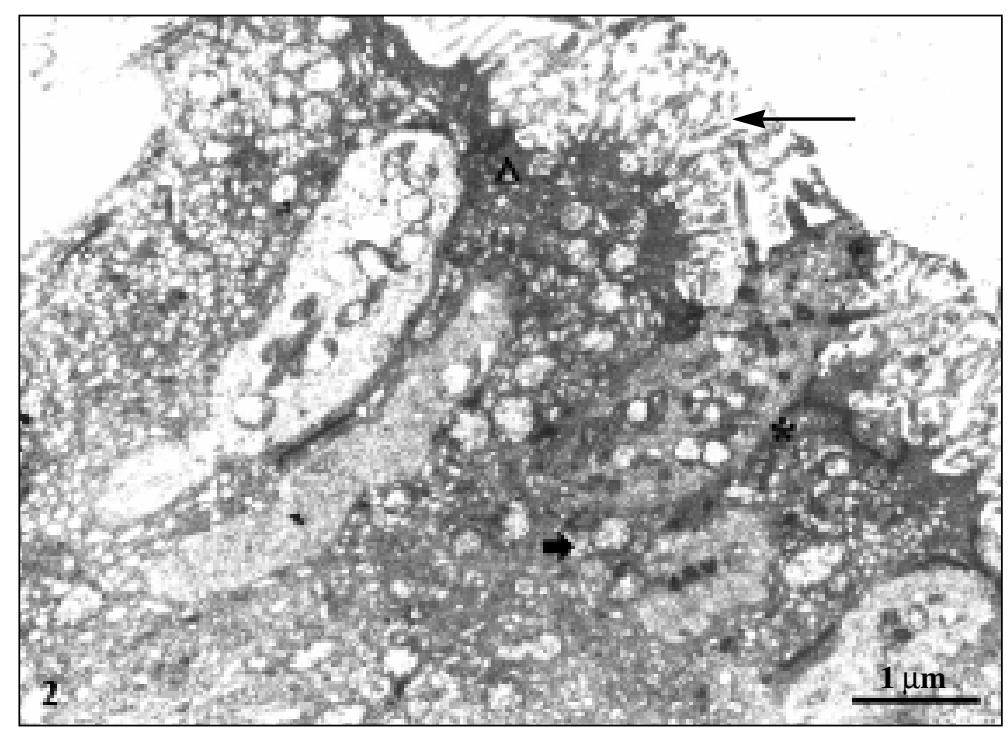

Fig. 2: Upper epithelial zone of kitten olfactory epithelium showing supranuclear segments of cytoplasm of sustentacular cells and dendritic projections of olfactory cells.

$\triangle \quad$ organelle-free band in apical segments of cytoplasm of sustentacular cell

$\Rightarrow$ bodies with a finely granular contents

* close links between adjacent cells

$\rightarrow$ numerous long microvili 
Plate II

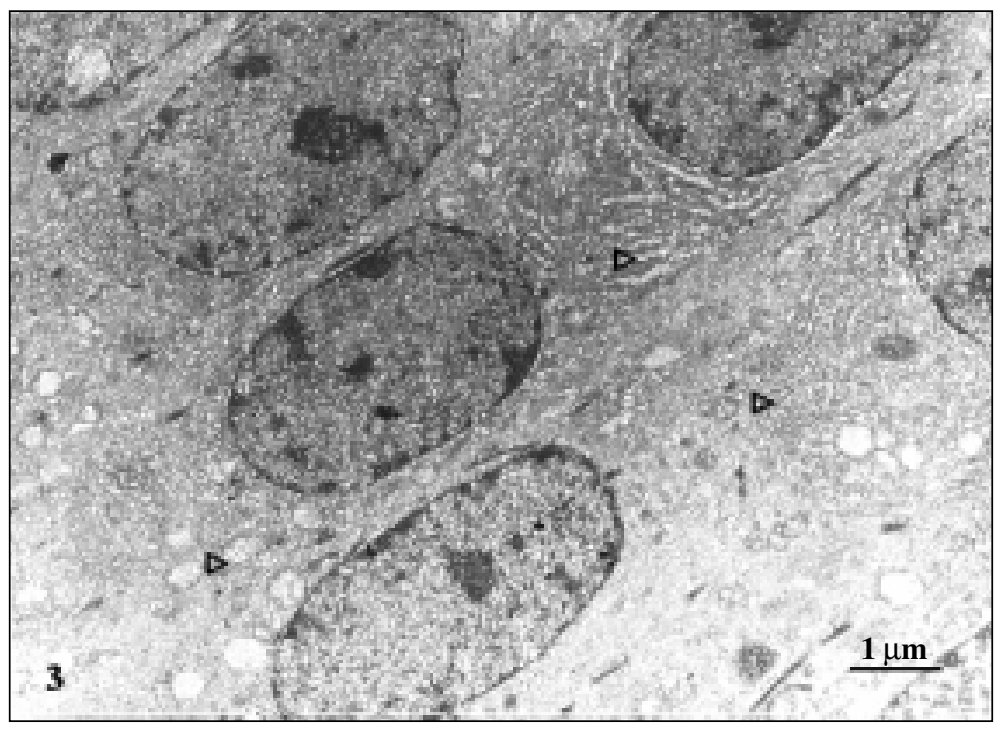

Fig. 3: The zone of sustentacular cell nuclei with plentiful organelles $(\triangleright)$, kitten olfactory epithelium.

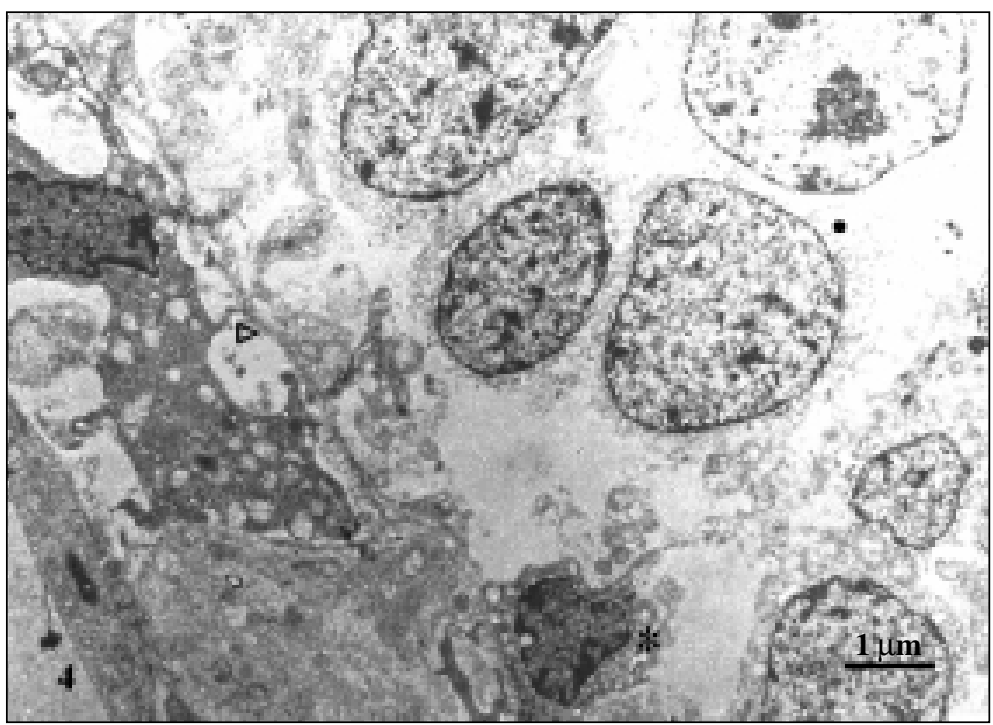

Fig. 4: Bottom part of the olfactory epithelium in a kitten with basal (*) and olfactory $(\bullet)$ cells. The thin basal membrane $(\triangleright)$ with the underlying lamina propria mucosae is visible. 